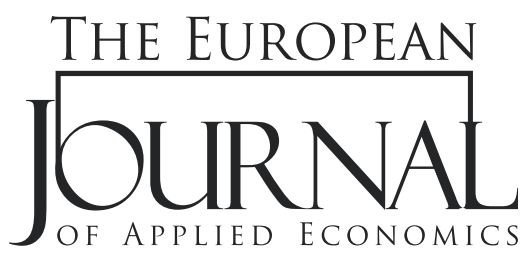

\title{
DOES URBANIZATION INTENSIFY CARBON EMISSIONS IN NIGERIA?
}

\author{
Muhammad Shehu* \\ Department of Social Sciences, \\ Federal Polytechnic, Bida, \\ Niger State
}

\begin{abstract}
:
This study examines the urbanization and $\mathrm{CO}_{2}$ emissions nexus in Nigeria using the Autoregressive Distributed Lag (ARDL) method to analyze the annual time series data spanning from 1974 to 2015. Findings suggest that urbanization, GDP, energy use, and carbon emissions are strongly and positively correlated, while trade and carbon emissions exhibit a weak and negative correlation. The ARDL result shows a negatively significant short-term and long-term connection between urbanization and carbon emission in the Nigerian economy. In the short-term, GDP, trade and energy use positively affect carbon emission while in the long-term, trade and GDP negatively affect carbon emissions with energy use having a positive impact on carbon emissions. The study, therefore, concludes that urbanization does not cause carbon emission to rise in Nigeria, but energy use does. From the findings, it was recommended that there is a need for the use of energy-saving and environmentally friendly technology to reduce the amount of carbon emission in the economy.
\end{abstract}

\section{Article info:}

Received: December 17, 2018

Correction: December 17, 2018

Accepted: January 25, 2019

\section{Keywords:}

ARDL,

$\mathrm{CO}_{2}$ emissions,

STIRPAT Model,

Urbanization.

\section{INTRODUCTION}

In the pursuit of sustainable energy development as one of the foremost goals of every nation, several factors must be taken into consideration. Chief among these are improved energy efficiency and sustainability (Liu et al., 2017). However, it has been argued that some of the main factors contributing to increased environmental degradation are economic activities and unrestricted energy use (Abdallh \& Abugamos et al 2017). Human activities undeniably contribute to an increase in greenhouse gases and depletion of the ozone layers. Furthermore, daily human activities in most cases inversely relate to the ecosystem and sometimes lead to environmental damages and, if not urgently addressed, may claim human lives and harm the significant factors of production (Ali et al., 2016a). Moreover, economies with poor environmental awareness and increased urbanization may trigger higher levels of environmental degradation. 
Although several researchers agree that urbanization increases output, economic profits, affluence and inspiration to reshape politics, arts, science, and other human interests in an economy (see, Stewart and Lee, 1986; Glaeser, 2011; and Ali et al., 2016, among others), Bloom et al. (2008) add that urbanization also triggers the quick spreading of infections, increased crime, poverty, and may also lead to the degradation of environmental quality. United Nations (2014) projects that rural-urban migration comes 2050 may increase to 70 percent from the 50 percent noted in 2014, and much of this is most likely to occur in Africa. Findings from this projection formed the major discussion at the 2016 Habbit III Conference which took place in Ecuador (Quito), with growing concerns on how to devise the means to avert the negative impact of urban growth on the environmental quality of the continent.

The relationship between urbanization and environmental quality has been a major source of controversy among notable scholars and policymakers. Remarkably, the recent literature is marked with various empirical claims about the connection between urbanization and environmental quality across different economies (see, for example, Zhu et al, 2012; Sadorsky, 2013; Wang et al., 2015; Ali et al., 2016; and Bilgili et al., 2017, among others). However, this paper investigates a sensible number of them and notices divergence in their findings. Factors, for example, the idea of nations examined, the models evaluated, the fundamental arrangement of statistical properties, estimation strategies utilized, and data coverage might be answerable for the varied discoveries.

This study revisited the literature on urbanization-environmental quality nexus on the following point of view: First, this paper investigates the connection between urbanization and environmental quality in Nigeria, and from the observations in the literature, a few investigations on the urbanizationenvironmental quality nexus has been carried out in Nigeria (see e.g., Martínez-Zarzoso, 2008; Enete and Ayadiulo, 2012; and Adusah-Poku, 2016), with inconclusive findings.

A study about Nigeria is important due to its massive population and rapid rate of development, all of which could negatively affect the country's environment. Secondly, this paper adopts the STIRPAT model (i.e. Stochastic Impact Regression on Population, Affluence and Technology), which has gained much attention in environmental policy analysis in most researches. The main idea behind the model is that the standard of living in urban centers and the demographics are factors considered in determining environmental quality. This is unlike the Environmental Kuznet Curve (EKC) hypothesis, which only considers an increase in per capita income as the main determinant of environmental quality and may lead to erroneous conclusions. Thirdly, the Autoregressive Distributive Lag (ARDL) model founded by Pesaran et al (2001), which is capable of considering time series of different orders of integration was adopted, while also allowing for structural breaks using the Bai - Perron unit root test which endogenously discovers as far as five (5) likely breaks. The issue of structural breaks is vital due to the evidence of volatility and significant changes in the time series data employed, and neglecting structural breaks in the data employed when they actually exist may lead to erroneous estimates. The study also adopts the Granger causality test to validate the causality nexus among urbanization and carbon emissions. In structural analysis, the positive hypothesis regarding the causal arrangement of the investigated data is required, while the subsequent causality effect of sudden surprises or advancement to stated variables on the variables used in the model are summarized.

Other parts of this paper are separated into four sections. The second part includes the literature review and the third part discusses the methodology used for the study. The fourth part presents the analytical framework of the study, while the last part concludes and proffers policies.

Other parts of this study are divided into four sections. The second section includes the literature review and section three discusses the methodology used for the study. The fourth section presents the analytical framework of the study, while the last section concludes and proffers policies from the findings. 


\section{LITERATURE REVIEW}

The Environmental Kuznet Curve proposition has spurred the interest of many scholars over the years. According to Kuznet (1956), as the economic activities of a country increases, it attracts more investment opportunities, and bring in cheaper labor from the rural areas to urban centers to participate in industrialization, ignoring the initial mainstay (agriculture) for a better-paying job. Kuznet (1956) argues that in the process of migrating, the average wage inequality will reduce after 50 percent of population has migrated, but will get to a certain stage whereby the effect will have an inverted U-shaped curve. Going by Kuznet proposition, the theory implies that as the number of rural-urban migration increase because of improved economic activities, the environmental quality of the economy starts to degenerate gradually. However, this has been found to be subjective as the data used by Kuznet (1956) were more of middle-income countries in Latin America, thus generating a debate as to its evidence in other country groups, particularly low-income countries.

Meanwhile, Dietz and Rosa $(1994,1997)$ argue against this assertion from the opinion that this model limits the determinant of environmental degradation to economic growth alone. They introduce the STIRPAT model which has gained much attention in environmental policy analysis in most researches. The main idea behind the model is that standard of living in the urban city and demographics are factors to be considered in determining environmental quality.

Empirically, Poumanyvong and Kaneko (2010) analyzed the urbanization effect on $\mathrm{CO}_{2}$ emissions and energy consumption using a STIRPAT model and a balanced panel data analysis for a sample of 99 nations spanning from 1975 to 2005. The study verified that the impact of urbanization on $\mathrm{CO}_{2}$ emissions and energy consumption depends on the levels of the economies development. It further subscribed that, urbanization reduces energy consumption in low-income class, and causes energy consumption for middle and high-income classes to rise. Besides, the study noted that urbanization in all the income groups positively impacted carbon emissions, but more was reflected in the middle and high-income classes. Zhu, You and Zeng (2012) revisited the Environmental Kuznet Curve (EKC) by analyzing the data spanning from 1992 to 2008 for 20 emerging countries using semi-parametric panel data model with fixed effects. They noted little evidence for the inverted U-shape and could not confirm the Kuznet hypothesis in their analysis as they found a nonlinear connection among urbanization and carbon emissions. Evidence from 16 emerging countries, Sadorsky (2014) leaned on the STIRPAT model and applied panel regression technique to assess the link between urbanization and carbon emissions between 1979 and 2009. The findings showed that the effect of urbanization on $\mathrm{CO}_{2}$ emissions in those countries is positive, but not statistically significant.

For the period 1983 to 2005, De Leon Barido \& Marshall (2014) examined how the national level of $\mathrm{CO}_{2}$ emissions reacted to urbanization and environmental policies in 80 countries by using panel data analysis. Findings from their study suggest that, for the random and fixed effects, carbon emission increases by $0.95 \%$ for every $1 \%$ increase in urbanization, and for every economy with a strong environmental policy, urbanization has demonstrated more benefits to environmental quality. Their result showed specifically that the elasticity effect for higher-income and lower-income countries are -1.1 and 0.21 for an economy with a strong environmental policy, while it is 0.65 and 1.3 for economies with a weaker environmental policy, respectively. Incorporating the quadratic form of urbanization into the STIRPAT model, Wang et al. (2015) also adopted semi-parametric panel data regression analysis to explore the carbon emissions impact of urbanization in OECD countries. They confirmed from their findings that the Environmental Kuznets Curve hypothesis holds in the OECD countries. 
For 22 urbanized emerging economies, Rafiq et al. (2016) clarified the link between urbanization, trade openness, $\mathrm{CO}_{2}$ emissions and energy intensity by employing heterogeneous panel data analysis for a dataset spanning the period 1980 to 2010 . The analysis showed that urbanization increases energy intensity and $\mathrm{CO}_{2}$ emissions, while trade openness reduces both energy intensity and $\mathrm{CO}_{2}$ emissions.

For the developing countries, Sadorsky (2013) adopts panel heterogeneous regression analysis to evaluate the energy intensity effect of industrialization, urbanization and income in 76 developing economies. The result reveals that energy intensity reduces by $-0.45 \%$ to -0.35 when income increase by $1 \%$. The elasticities of industrialization stretch between 0.07 to 0.12 in the long-term. The study further argued that the urbanization impact on energy intensity is mixed as its coefficient is slightly greater than unity when it is statistically significant. In China, Sheng and Guo (2016) applied dynamic fixed effect technique, pooled mean group, and mean group to assess the urbanization impact on $\mathrm{CO}_{2}$ emissions in both short-term and long-term using the data between 1995 and 2011. The findings suggested that urbanization would have a long-lasting impact on $\mathrm{CO}_{2}$ emissions in the economy of China. Ali et al. (2016a) used the ARDL model to examine the impact of urbanization on carbon emission in the economy of Singapore between 1970 and 2015. Their findings revealed that urbanization had a strong adverse impact on $\mathrm{CO}_{2}$ emissions, while economic growth appeared to impact positively on carbon emission in the economy. They argued that urbanization should not be considered an obstacle to environmental quality when considering policies.

Similar to the findings of Ali et al. (2016b), Pata (2017) examines the relationship between urbanization, industrialization, and carbon emission in Turkey between 1974 and 2013 using the ARDL model. The study concludes that in Turkey, urbanization and industrialization decrease the level of environmental quality captured by an increase in carbon emissions per head. In a study carried out on urbanization-carbon emission nexus in 20 MENA using semi-parametric panel fixed effects regression together with panel data between the period of 1980 and 2014, Abdallh and Abugamos (2017) discover little proof for EKC hypothesis, because the environmental quality of the region is found to be significantly supported by urbanization. They further conclude that economic growth and energy consumption are the major causes of $\mathrm{CO}_{2}$ emissions in the region.

Liu, Yu and Gong (2017) investigates the effect of urbanization and ageing on energy intensity using two-way fixed effect model. Their findings reveal ageing negatively impacts energy intensity, energy intensity and GDP per capita are positively affected by urbanization, while energy prices and productivity negatively affect energy intensity. Bilgili et al. (2017) adopt the panel data analysis to examine urbanization-energy intensity nexus in 10 Asian countries between 1990 and 2014. They observe that urbanization has a significantly negative effect on energy intensity in both short-term and long-term. Using the threshold vector error correction method, Liu and Xie (2013) confirmed that the causality connection between energy intensity and urbanization in China is nonlinear. Similarly, $\mathrm{Zi}$ et al. (2015) examine the link between urbanization and carbon emissions in China using a threshold model. Arguments from their findings suggest the pattern of thresholds varies geographically, and emissions increase when the threshold of 0.43 is surpassed as residential income increases. Moreover, an increase in urbanization and industry percentage in overall GDP causes carbon emissions to rise and fall respectively.

From a comparative study of the urbanization influence on $\mathrm{CO}_{2}$ emissions for the economy of China and Japan, Ouyang and Lin (2016) find a similar result for the economies as $\mathrm{CO}_{2}$ emissions show increasing growth during urbanization process in the economies, but a significant difference exists considering energy intensity, energy structure, and carbon dioxide emissions per capita among the two 
countries, which serves as a determining factor for carbon dioxide emissions growth. He et al. (2016) analyze the provincial panel data from 1995 to 2013 for china using the STIRPAT model. They divided the 29 provinces into 3 regions. Findings from the study reveal that the EKC hypothesis hold for the major regions of China. For region 2 and 3, urbanization negatively affects carbon dioxide emissions, while for region 1, only population influences emissions, and not urbanization. Zhang et al. (2017) incorporate a panel data consisting of 141 nations spanning between 1961-2011 into a STIRPAT model. Their results for urbanization and $\mathrm{CO}_{2}$ emissions nexus confirm EKC hypothesis and the turning point is around 73.8\%. Yang et al. (2017) employ data from 266 prefecture-level cities between 2000-2010 to analyze the urbanization effect on energy used and economic growth in China using the Pooled Ordinary Least Squares (POLS) method. Results from their findings show urbanization positively and significantly affect energy used and economic growth within the period. Wang et al. (2015) study nexus among urbanization, energy consumption, and $\mathrm{CO}_{2}$ emissions in the ASEAN countries between 1980 and 2009 using panel fully modified ordinary least squares method. It was observed that $\mathrm{CO}_{2}$ emissions rise by $0.20 \%$ whenever urban population increases by $1 \%$, a unidirectional causal nexus running from urbanization to $\mathrm{CO}_{2}$ emissions and energy consumption.

Martínez-Zarzoso (2008) employs heterogeneous panel data regression analysis to examine the relationship between $\mathrm{CO}_{2}$ emissions and urbanization in selected developing countries. These countries are grouped into three (3); the low group, low-middle-income group and the upper-middle-income group. Findings from the study show that the impact of urbanization is higher than unity, 0.72, and negative for low-income group, low-middle-income group, and upper-middle-income group respectively. Adusah-Poku (2016) investigates the nexus between urbanization, population, and carbon emission in 45 sub-Saharan African countries using pooled mean group (PMG) to analyze the dynamic heterogeneous panels of the data spanning from 1990 to 2010. The study validates a short-term and long-term positive impact of both urbanization and population on carbon emissions and tends to grow faster in economies such as Nigeria and Ethiopia with larger populations, compared to the countries with smaller populations, such as Cape Verde and Equatorial Guinea. Ali et al., (2016b) for the economy of Nigeria adopts the ARDL method and STIRPAT model to explore the effect of energy use, economic growth, urbanization, and trade on $\mathrm{CO}_{2}$ emissions in Nigeria. Findings from the study suggest energy consumption, economic growth, and urbanization positively impact $\mathrm{CO}_{2}$ emissions in Nigeria in both short-term and long-term.

In conclusion, it is evident from the review of literature that, while there have been several studies investigating carbon emissions and its relationship across different factors, little or no country-specific study exists on urbanization-carbon emissions nexus in Nigeria. Most of these studies have been subjective and qualitative in nature. The point of departure to this study lies in the adoption of the STIRPAT framework while also making use of the ARDL model, which accounts for the impact of the structural break in analyzing the nexus between urbanization and carbon emissions in Nigeria.

\section{Data and Methodology}

The study adopts the STIRPAT model in line with the work of Poumanyvong and Kaneko (2010), Ali et al., (2016b), Ali et al., (2016a), and Zhang et al., (2017) to analyse the link between urbanization and $\mathrm{CO}_{2}$ emissions in Nigeria. The IPAT model accounts for urbanization as a factor that contributes to increased carbon emissions in the economy. Dietz and Rosa (1994) introduce the Stochastic type of the IPAT equation. 
The equation encompasses quantitative variables of population size (P), affluence per capita (A), and industrial weight in economic interaction measured as a polluting technology $(\mathrm{T})$. It is a year based model, specified as;

$$
I_{i}=a P_{i}^{\beta_{o}} A_{i}^{\beta_{1}} T_{i}^{\beta_{2}} \varepsilon_{i}
$$

Where: $I_{i}, P_{i}, A i$, and $T_{i}$ indicate environmental impact (I) population (P), affluence (A), and technology (T) in an economy. $i, \alpha, \beta$ are the parameters to be estimated; and $\mathcal{E}_{i}$ is the random error term. According to the pioneers, Dietz and Rosa $(1994,1997)$, STIRPAT is mainly applied to study the factors that affect the environment. The main argument behind the model is that $\mathrm{CO}_{2}$ emission is produced by demographics, but varies on the highly efficient standard of living in the urban city. Ali et al., (2016a) submitted that the economic activities in the urban cities may have two different effects: those connected to higher consumption and incomes that promote industrialisation, and attracts the use of fossil fuels.

Following the views of the authors, the model for this study is formulated by adapting the model of Ali et al., (2016b) in the economy of Nigeria, which implies that urbanization, energy use, GDP, and trade are the main factors influencing carbon emissions in the country. The model is, therefore written as:

$$
C O_{2}=(G D P, E U, U, T)
$$

Energy consumption per capita (oil equivalent), Urbanization rate, and Trade (calculated as the ratio of import plus export to GDP at current LCU). respectively Equation (2) is further transformed into a logarithm function as:

$$
\operatorname{InCO} O_{2}=\beta_{0}+\beta_{1} \operatorname{In} G D P_{t}+\beta_{2} \operatorname{InE} U_{2}+\beta_{3} U_{t}+\beta_{4} T_{2}+\varepsilon_{t}
$$

For this study, the ARDL model, which is permitted for variables stationary at $\mathrm{I}(0), \mathrm{I}(1)$, or a combination of $\mathrm{I}(0) \& \mathrm{I}(1)$ is used. It is also used because of its ability to estimate both the short-run and long-run magnitudes, as well as the error correction value.

In order to estimate equation (3), the associated conditional standard autoregressive distributed lag $\operatorname{ARDL}\left(\boldsymbol{p}, \boldsymbol{j}_{1}, \mathbf{j}_{2}, \boldsymbol{j}_{3}, \mathbf{j}_{4}\right)$ long run model for $\mathrm{CO}_{2 i}$ can be expressed as:

$$
\operatorname{InCO} C_{2 t}=c_{0}+\sum_{q=1}^{p} \beta_{1} \operatorname{InCO} O_{t_{t-1}}+\sum_{q=0}^{j_{1}} \beta_{2} \operatorname{In} G D P_{t-i}+\sum_{q=0}^{j_{2}} \beta_{3} \operatorname{InE} U_{t-i}+\sum_{q=0}^{j_{3}} \beta_{4} \operatorname{In} U_{t-i}+\sum_{q=0}^{j_{4}} \beta_{5} T_{t-i}+\varepsilon_{t}
$$

However, accounting for structural breaks, the breaks are captured using $\sum_{r=1}^{s} B_{r}$ Dummy $y_{r t}$ in equation 5 where Dummy $y_{r t}$ is a dummy variable accounting for every breaks termed as Dummy $y_{r t}=1$ for $t>T_{B}$ or else Dummy $y_{r t}=0 . t$ represents the time period; $T_{B}$ are the dates of the structural break, where $\mathrm{r}=1,2,3, \ldots \ldots, k$ and $\mathrm{Br}$ is the break dummy coefficient.

$$
I n C O_{2 t}=c_{0}+\sum_{q=1}^{p} \beta_{1} \operatorname{InCO}_{2_{t-1}}+\sum_{q=0}^{j_{1}} \beta_{2} \operatorname{InGDP} P_{t-i}+\sum_{q=0}^{j_{2}} \beta_{3} \operatorname{InE} U_{t-i}+\sum_{q=0}^{j_{3}} \beta_{4} \operatorname{In} U_{t-i}+\sum_{q=0}^{j_{4}} \beta_{5} T_{t-i}+\sum_{q=0}^{s} \beta_{r} D_{u m m y}+\varepsilon_{t}
$$

The short-term dynamic parameters of the impact of urbanization on carbon emission is obtainable by estimating the equation as; 


$$
\Delta I n C O_{2 t}=\vartheta_{0}+\sum_{q=1}^{p} p_{1} \Delta I n C O_{2_{t-j}}+\sum_{q=0}^{j_{1}} p_{2} \Delta I n G D P_{t-j}+\sum_{q=0}^{j_{2}} p_{3} E U_{t-j}+\sum_{q=0}^{j_{3}} p_{4} U_{t-j}+\sum_{q=0}^{j_{4}} 5_{5} \Delta T_{t-j}+\vartheta e c m+\varepsilon_{t}
$$

From equations 4 to $6, \beta_{1}-\beta_{5}$ serves as the variables long-term multiplier. While $p_{1}-p_{5}$ are the variables short-term multipliers, $c_{0}$ and $\vartheta_{0}$ are the long-term and short-term intercept of the models. $j_{1}-j_{4}$ are the length of optimal lags for each of the variables. $e c m_{t-1}$ is the error correction term defined as;

$$
E C M_{t-1}=\Delta I n C O_{2 t}-\vartheta_{0}-\sum_{q=1}^{j_{1}} p_{2} \Delta G D P_{t-j}-\sum_{q=1}^{j_{2}} p_{3} E U_{t-j}-\sum_{q=1}^{j_{3}} p_{4} U_{t-j}-\sum_{q=1}^{j_{4}} p_{5} \Delta T_{t-j}
$$

The causal link between the dependent and independent variables is tested using the granger causality test. The model is expressed as;

$$
\Delta Z_{t}=\mu_{t}+\sum_{t=1}^{p-1} \Gamma_{i} \Delta Z_{t-1}+\Pi Z_{t-p}+\varepsilon_{t}
$$

$Z_{t}$ is a $5 \mathrm{x} 1$ vector matrix of the endogenous variables $\left(\mathrm{CO}_{2}\right.$, GDP, EU, $\mathrm{U}$ and $\left.\mathrm{T}\right) . \Gamma_{i} \Delta Z_{t-1}+\Pi Z_{t-p}$ is a vector, with a lag operator and $\in_{t}$, a vector of idiosyncratic errors.

\section{Discussion of Results}

\section{Descriptive Statistics}

The descriptive statistics result represented in Table 1 shows that the variables' value for mean lies within their lowest and highest values. On average, within the period under study, the variables- $\mathrm{CO}_{2}$, Urbanization, GDP per capita, Energy use and Trade grow an average of 11.13\%, 34.96\%, $10.02 \%, 6.58 \%$ and $0.51 \%$ respectively. The result of the skewness reveals that carbon emissions, per capita GDP, and trade are negatively skewed, while Urbanization and energy use reveal a positive skewness. Following the kurtosis result, the study concludes that the variables are leptokurtic in nature, as they have values less than three. The Jarque-bera statistics result showed that the entire variables are normally distributed with a probability distribution value greater than $10 \%$.

Table 1: Descriptive Statistics

\begin{tabular}{lccccc}
\hline & InCO $_{2}$ & UR & InGDP & InEU & T \\
\hline Mean & 11.1296 & 34.9636 & 10.0177 & 6.5763 & 0.5120 \\
\hline Maximum & 11.5588 & 47.7760 & 13.1718 & 6.6825 & 0.8181 \\
\hline Minimum & 10.4123 & 23.3890 & 6.5405 & 6.5095 & 0.2112 \\
\hline Std. Dev. & 0.3657 & 7.1085 & 2.2210 & 0.0486 & 0.1685 \\
\hline Skewness & -0.5181 & 0.1835 & -0.1797 & 0.4250 & -0.2433 \\
\hline Kurtosis & 1.8397 & 1.9466 & 1.7330 & 1.9878 & 2.0274 \\
\hline Jarque-Bera & 3.4282 & 1.7629 & 2.4574 & 2.4750 & 1.6754 \\
\hline Probability & 0.1801 & 0.4142 & 0.2927 & 0.2901 & 0.4327 \\
\hline Observations & 34 & 34 & 34 & 34 & 34
\end{tabular}

Source: Author's Computation (2018) 


\section{Correlation Test}

The correlation result showed that the correlation relationship between the entire variables and carbon emissions is strongly positive and statistically significant, except for trade, which was negative and insignificant. This means that strong nexus exists among energy use-carbon emission, GDP-carbon emission, urbanization-carbon emission, and are significant at 1\%, while the weak negative relationship between trade and $\mathrm{CO}_{2}$ emission is insignificant and weak. This validates the absence of the multicollinearity problem among the variables. The result is presented in Table 2 below:

Table 2 Correlation Matrix Test Results

\begin{tabular}{|c|c|c|c|c|c|}
\hline & $\mathrm{InCO}_{2}$ & UR & InGDP & InEU & $\mathbf{T}$ \\
\hline \multirow{2}{*}{$\mathrm{InCO}_{2}$} & 1 & & & & \\
\hline & ----- & & & & \\
\hline \multirow[t]{2}{*}{ UR } & 0.6044 & 1 & & & \\
\hline & $(0.0002)$ & ---- & & & \\
\hline \multirow[t]{2}{*}{ InGDP } & 0.5536 & 0.9823 & 1 & & \\
\hline & $(0.0007)$ & $(0.0000)$ & ----- & & \\
\hline \multirow[t]{2}{*}{ InEU } & 0.7237 & 0.8749 & 0.8532 & 1 & \\
\hline & $(0.0000)$ & $(0.0000)$ & $(0.0000)$ & ---- & \\
\hline \multirow[t]{2}{*}{$\mathbf{T}$} & -0.1903 & 0.1264 & 0.2443 & 0.0919 & 1 \\
\hline & $(0.2811)$ & $(0.4761)$ & $(0.1638)$ & $(0.6053)$ & ----- \\
\hline
\end{tabular}

( ) in parenthesis denotes the probability values of the variables

Source: Author's Computation (2018)

\section{Unit Root Test}

As a prerequisite for analyzing time series data with large $\mathrm{T}$, it is common practice in the literature to test the series for non-stationarity. Hence, the study subjects all the series used in the model to unit root testing. The study adopts the Ng-Perron test for stationarity. The null-hypothesis of the nonstationary test states there is absent of unit root among the series.

The unit root test is a compulsory test to show if the data used for the study are free from unit root problems. From the results in Table 3, the variables are stationary at $\mathrm{I}(0)$ and $\mathrm{I}(1)$. This suggests the presence of unit root problem in the data used as all the variables are not mean, reverting at levels as some only converge to long-term equilibrium after first differencing. To check if there is a long-term relationship among the variables, the ARDL bounds test is employed. Another innovation of this study is the adoption of the Bai-Perron (2003) structural break test, which is capable of determining five (5) possible breaks endogenously. Testing for structural breaks allows us to deal with multiple structural changes in the model, failure of which could lead to spurious conclusions. Capturing the structural breaks link between Urbanization-Carbon emission nexus is, however, the first in the context of Nigeria. 
Table 3: Ng Perron Unit Root Test Results [Trend and Intercept]

\begin{tabular}{|c|c|c|c|c|}
\hline & MZa & MZt & MSB & MPT \\
\hline \multicolumn{5}{|c|}{ Levels } \\
\hline $\mathrm{InCO}_{2}$ & -6.340 & -1.776 & 0.280 & 14.371 \\
\hline $\mathbf{U}$ & $-33.766^{* * *}$ & $-4.040^{\star * *}$ & $0.120^{* * *}$ & $3.080^{* * *}$ \\
\hline InGDP & -6.579 & -1.672 & 0.254 & 13.884 \\
\hline InEU & $-18.095^{\star * *}$ & $-2.978^{\star * *}$ & $0.165^{\star * *}$ & $5.213^{\star * *}$ \\
\hline $\mathrm{T}$ & -7.118 & -1.674 & 0.235 & 13.072 \\
\hline \multicolumn{5}{|c|}{ First Difference } \\
\hline $\mathrm{InCO}_{2}$ & $-15.960^{*}$ & $-2.824^{\star}$ & $0.177^{\star}$ & $5.716^{\star}$ \\
\hline $\mathbf{U}$ & -4.835 & -1.555 & 0.322 & 18.847 \\
\hline InGDP & $-15.750^{*}$ & $-2.781^{\star}$ & $0.177^{\star}$ & $5.935^{\star}$ \\
\hline InEU & $-15.859^{\star}$ & $-2.773^{\star}$ & $0.175^{\star}$ & $5.995^{\star}$ \\
\hline $\mathbf{T}$ & $-15.025^{\star * *}$ & $-2.733^{\star * *}$ & $0.182^{\star * *}$ & $1.659^{* * *}$ \\
\hline
\end{tabular}

Note: $*, * *, * * *$ implies the level of significance at $10 \%, 5 \%$ and $1 \%$ respectively.

Source: Author's Computation (2018)

The optimal lag test was also carried out in the study to know the correct number of lags to use for the study. Schwarz Information Criteria (SIC) was used to decide on the optimal lag length. The finding shows an optimal lag selection of 2 , which was used in the study. Table 4 below shows the result:

Table 4: Optimal Lag test result

\begin{tabular}{ccccccc}
\hline Lag & LogL & LR & FPE & AIC & SIC & HQ \\
\hline 0 & -21.6378 & NA & $3.84 \mathrm{E}-06$ & 1.7186 & 1.9499 & 1.79396 \\
\hline 1 & 176.02 & 318.803 & $5.72 \mathrm{E}-11$ & -9.4207 & -8.0329 & -8.9683 \\
\hline 2 & 219.8772 & $56.5898^{* * *}$ & $1.94 \mathrm{E}-11$ & -10.6372 & $-8.0931^{\star * *}$ & -9.8079 \\
\hline 3 & 254.5179 & 33.5233 & $1.54 \mathrm{e}-11^{* * *}$ & $-11.2592^{* * *}$ & -7.5586 & $-10.0529^{* * *}$ \\
\hline
\end{tabular}

Source: Author's Computation (2018)

The result of the bounds test reveals the existence of a cointegrating link among the variables in the long-term. This is validated by F-statistic value found to exceed the maximum and the minimum bound class of the variables at a 5\% significance level. The result is showed in table 5 below:

Table 5: ARDL Bounds Test Result

\begin{tabular}{ccccc}
\hline DEP/VARIABLES & F-Stat & \multicolumn{2}{c}{ Bounds (5\%) } & Outcome \\
\hline InCO $_{2 \mathbf{t}}=\mathbf{f}\left(\mathbf{U R}_{\mathbf{t}}, \operatorname{InGDP}_{\mathbf{t}}, \operatorname{InEU}_{\mathbf{t}}, \mathbf{T}_{\mathbf{t}}\right)$ & 4.75 & $\mathrm{I}(0)$ & $\mathrm{I}(1)$ & Co-integration \\
\hline
\end{tabular}

Source: Author's Computation (2018) 
In addition, the study examines the significance of structural breaks in the urbanization-emissions nexus. To determine the breaks, the Bai-Perron (2003) test was adopted; therefore incorporated into the model as fixed regressors in the ARDL model. The Bai-Perror break test result is reported in Table 6 below, and only one break is recorded for Nigeria. The break date identified to correspond with the sequence of OPEC cuts during that period which may have affected energy use.

Table 6: Bai-Perron (2003) Structural Break Dates

\begin{tabular}{ccc}
\hline Country & Break Period & Break Range \\
\hline \multirow{2}{*}{ Nigeria } & 2000 & $1982-1999$ \\
& & $2000-2015$ \\
\hline
\end{tabular}

Compiled by the author

\section{ARDL Estimation}

From the results of the unit root test, it was revealed that all the variables examined were not integrated of order 2, and therefore, we go on to estimate the ARDL model. As a benchmark, we first ran the ARDL model analysis without considering structural breaks. This was done to establish the existence of a long-term nexus among the variables. To carry out this, we used F-test proposed by Pesaran et al. (2001) to test the null hypothesis of no cointegration against the alternative hypothesis of co-integration. The maximum of 2 lags suggested by SIC is used as an optimal number of lags on each first-differenced variable. The results of the bounds test suggest that a long-term co-integrating nexus exists among the variables. This is validated by F-statistic value found to exceed both the upper and lower bound class of the variables at a 5\% significance level (see Table 5).

The long-term and short-term ARDL estimation result for both scenarios (with and without breaks) are presented in Table 7. In the short-term, findings from the result support the presence of a significantly negative connection between urbanization and carbon emissions in Nigeria. Significantly, a unit development in urbanization results in approximately $50 \%$ reduction in carbon emissions. Similarly, the result reveals an adverse significant connection between trade and $\mathrm{CO}_{2}$ emissions both with and without breaks. In the same vein, evidence supports the presence of a negatively significant connection between GDP and carbon emissions. Specifically, a percentage increase in GDP leads to approximately $33 \%$ reduction in carbon emissions in the short-term. However, taking structural breaks into account, the relationship is positive but insignificant.

On the other hand, energy used exhibits a positively significant connection with carbon emissions in Nigeria. In particular, a percentage increase in energy use will cause carbon emissions to rise by $6.16 \%$ in the short-term, and a similar result was observed while accounting for breaks. This implies that irrespective of the consideration of breaks, the energy use affects carbon emissions negatively.

From the short-term results, it can be deduced from the result that increases in carbon emissions in Nigeria can actually be attributed to increased energy consumption, not urbanization. Overall, the result reveals that the independent variables have the ability to correct about $76 \%$ of deviations of emissions from the expected equilibrium in the long-term back to equilibrium. This satisfies the a priori expectation of the error correction result which is negatively significant at a $1 \%$ significance level. The result can be seen in Table 7 . 
The long-term results from the model estimation provide evidence on behalf of a significantly negative connection between carbon emissions and urbanization, GDP, and trade in Nigeria. In particular, a unit change in urbanization and trade and a percentage change in GDP causes emission to fall by $65 \%$, $1.78 \%$ and $1.09 \%$ respectively. Similar to observations in the short-term, there is strong evidence of a positively significant connection between energy use and carbon emissions with and without breaks.

From the ARDL findings, the results are found to be in consonance and against the submission of some existing studies. The long-term and short-term results of the urbanization-carbon emission nexus is against the submission of Sadorsky (2014) for 16 emerging countries, de Leon and Marshall (2014) for 80 countries, Ouyang and Lin (2016) for Japan and China, and Wang et al., (2016) for ASEAN countries, but confirms the findings of Ali et al. (2016a) for Singapore and Pata (2017) for Turkey, in that a negatively significant nexus exists between urbanization and $\mathrm{CO}_{2}$ emissions in Nigeria. The results deviate from the submission of these studies because they are panel analyses and not country-specific. Against the study of Ali et al., (2016b) for Nigeria, the study argued that the reaction or changes in consumer behaviour towards energy consumption due to the implementation of several environmental policies (such as the Paris Climate Change Agreement) and the introduction of new energy-efficient technologies (solar systems, among others) into the economy may have caused the deviation of the study findings from Ali et al. (2016b) in the long-term. The findings of our study conformed with that of Ali et al. (2016b) which only exist in the short-term, but are not valid in the long-term. Moreover, the result agrees with Bilgili et al. (2017) and Abdallh and Abugamos (2017) that urbanization is a significant determinant factor of reduction in carbon emissions in Nigeria. The findings also corroborate the findings of Abdallh and Abugamos (2017), which state that energy use is the major source of carbon emissions in a developing country like Nigeria.

Finally, findings from the study suggest breaks are significant in urbanization-carbon emissions nexus in Nigeria in both the long-term and the short-term. Moreover, the results of the diagnostic checks suggest the absence of serial correlation and heteroscedasticity (see Table 7):

Table 7: ARDL Estimation Result

\begin{tabular}{lcc}
\hline \multicolumn{1}{c}{ Variables } & ARDL Without Breaks & ARDL With Breaks \\
\hline Constant & Long Run Results & \\
& -23.9420 & -48.0845 \\
\hline Trend & $(-2.5149)^{* *}$ & $(-4.0273)^{* * *}$ \\
& 0.7048 & 0.5117 \\
UR & $(6.9686)^{* * *}$ & $(3.2651)^{* * *}$ \\
\hline lnGDP & -0.6547 & -0.5528 \\
& $(-6.5520)^{* * *}$ & $(-4.2557)^{* * *}$ \\
\hline lnEU & -1.0932 & -0.6462 \\
& $(-5.3958)^{* * *}$ & $(-2.2420)^{* *}$ \\
\hline T & 8.8199 & 11.7661 \\
& $(5.7639)^{* * *}$ & $(5.9487)^{* * *}$ \\
\hline B & -1.7795 & -2.1752 \\
& $(-4.8019)^{* * *}$ & $(-5.3343)^{* * *}$ \\
\hline
\end{tabular}




\begin{tabular}{|c|c|c|}
\hline \multicolumn{3}{|c|}{ Short Run Results } \\
\hline \multirow{2}{*}{ Constant } & -18.2453 & -53.9210 \\
\hline & $(-2.6459)^{* *}$ & $(-3.8023)^{* * *}$ \\
\hline \multirow{2}{*}{$\Delta$ Trend } & 0.5371 & 0.5738 \\
\hline & $(5.5315)^{* * *}$ & $(3.0594)^{* *}$ \\
\hline \multirow{2}{*}{$\Delta \ln C O_{2 t-1}$} & & 0.3303 \\
\hline & -- & $(2.1840)^{\star}$ \\
\hline \multirow{2}{*}{$\Delta U R$} & -0.4989 & -0.6199 \\
\hline & $(-5.9901)^{* * *}$ & $(-3.9151)^{* *}$ \\
\hline \multirow{2}{*}{$\Delta \ln G D P$} & -0.3341 & 0.0048 \\
\hline & $(-2.2275)^{* *}$ & $(0.0325)$ \\
\hline \multirow{2}{*}{$\Delta \ln G D P_{t-1}$} & 0.2355 & 0.3839 \\
\hline & $(1.4856)$ & $(1.6861)$ \\
\hline \multirow{2}{*}{$\Delta \ln E U$} & 6.7213 & 6.1678 \\
\hline & $(5.5443)^{* * *}$ & $(4.4224)^{* * *}$ \\
\hline \multirow{2}{*}{$\Delta \ln E U_{t-1}$} & -- & -0.2128 \\
\hline & -- & $(-0.1164)$ \\
\hline \multirow{2}{*}{$\Delta \ln E U_{t-2}$} & -- & -0.3435 \\
\hline & - & $(-0.1901)$ \\
\hline \multirow{2}{*}{$\Delta \ln E U_{t-3}$} & & -3.3827 \\
\hline & -- & $(-2.3898)^{* *}$ \\
\hline \multirow{2}{*}{$\Delta T$} & -0.6509 & -1.0811 \\
\hline & $(-2.8461)^{* * *}$ & $(-3.9002)^{* * *}$ \\
\hline \multirow{2}{*}{$\Delta T_{t-1}$} & 0.5597 & 0.3862 \\
\hline & $(2.2781)^{\star *}$ & $(1.6740)$ \\
\hline \multirow{2}{*}{$\Delta T_{t-2}$} & -- & 0.4786 \\
\hline & - & $(1.8959)^{\star}$ \\
\hline \multirow{2}{*}{$\Delta T_{t-3}$} & -- & 0.7660 \\
\hline & -- & $(2.6880)^{* *}$ \\
\hline \multirow{2}{*}{$B$} & -- & 0.3885 \\
\hline & - & $(1.8897)^{*}$ \\
\hline \multirow{2}{*}{$E C M_{t-1}$} & -0.7621 & -1.1214 \\
\hline & $(-6.3034)^{* * *}$ & $(-8.1050)^{* * *}$ \\
\hline F-stat. & $26.4063^{* * *}$ & $30.7841^{\star * *}$ \\
\hline Bound F-stat. & $4.7482^{\star *}$ & $14.1064^{\star * *}$ \\
\hline $\operatorname{Adj.} R^{2}$ & 0.8913 & 0.9487 \\
\hline \multirow{2}{*}{ J.B stat } & 0.7981 & 0.3384 \\
\hline & {$[0.6710]$} & {$[0.8443]$} \\
\hline \multirow{2}{*}{$L M(1)$} & 0.5795 & 1.2491 \\
\hline & {$[0.5698]$} & {$[0.3321]$} \\
\hline \multirow{2}{*}{$A R C H(1)$} & 0.7556 & 0.0161 \\
\hline & [0.3919] & {$[0.9001]$} \\
\hline \multirow{2}{*}{ Ramsey test } & 7.5344 & 2.1748 \\
\hline & {$[0.0125]$} & {$[0.1711]$} \\
\hline Lag Selection (SIC) & $(1,0,2,0,2)$ & $(2,0,2,4,4)$ \\
\hline
\end{tabular}

$B$ represents dummy for the identified break date as identified in the Bai Perron test presented in Table 6. Standard errors are presented in brackets and probability values are presented in parentheses. The critical values for the Lower and Upper Bounds respectively are 3.03 and 4.06 for the symmetric models at 10\% significance level. $* * *, * *$, and $*$ indicate statistical significance at $1 \%, 5 \%$ and $10 \%$ respectively. 


\section{Granger Causality Test}

Further testing on the causality nexus among the variables that was carried out. From the result, it was discovered that a uni-directional causality nexus between $\mathrm{CO}_{2}$ to urbanization and $\mathrm{CO}_{2}$ to trade at a 5\% significance level. This implies that emissions drive urbanization and that urbanization does not explain emissions in Nigeria. Likewise, there is no causality nexus between GDP and $\mathrm{CO}_{2}$, EU and $\mathrm{CO}_{2}$. The implication of this is that emission is the reason behind the act of urbanization in Nigeria. See the result below in Table 8:

Table 8: Granger Causality Result

\begin{tabular}{|c|c|c|c|}
\hline Null Hypothesis: & Obs & F-Statistic & Prob. \\
\hline UR does not Granger Cause LOGCO & 32 & 1.1785 & 0.3231 \\
\hline LOGCO does not Granger Cause UR & & 9.9270 & 0.0006 \\
\hline LOGGDP does not Granger Cause LOGCO & 32 & 1.5367 & 0.2333 \\
\hline LOGCO does not Granger Cause LOGGDP & & 1.3275 & 0.2819 \\
\hline LOGEU does not Granger Cause LOGCO & 32 & 1.6443 & 0.2119 \\
\hline LOGCO does not Granger Cause LOGEU & & 0.0413 & 0.9596 \\
\hline T does not Granger Cause LOGCO & 32 & 0.4359 & 0.6511 \\
\hline LOGCO does not Granger Cause T & & 3.8337 & 0.0342 \\
\hline LOGGDP does not Granger Cause UR & 32 & 0.4437 & 0.6462 \\
\hline UR does not Granger Cause LOGGDP & & 1.0920 & 0.3499 \\
\hline LOGEU does not Granger Cause UR & 32 & 0.0478 & 0.9534 \\
\hline UR does not Granger Cause LOGEU & & 6.7583 & 0.0042 \\
\hline T does not Granger Cause UR & 32 & 1.0835 & 0.3527 \\
\hline UR does not Granger Cause T & & 1.4061 & 0.2625 \\
\hline LOGEU does not Granger Cause LOGGDP & 32 & 2.8221 & 0.0771 \\
\hline LOGGDP does not Granger Cause LOGEU & & 3.6717 & 0.0389 \\
\hline T does not Granger Cause LOGGDP & 32 & 0.8766 & 0.4277 \\
\hline LOGGDP does not Granger Cause T & & 2.5914 & 0.0934 \\
\hline T does not Granger Cause LOGEU & 32 & 0.9376 & 0.4039 \\
\hline LOGEU does not Granger Cause T & & 3.2484 & 0.0544 \\
\hline
\end{tabular}

Source: Author's computation (2018). 


\section{CONCLUDING REMARKS}

This paper investigates the link between urbanization and carbon dioxide emission in Nigeria using annual data from 1984 to 2015 . The ARDL technique is used to analyse the data. Results from the study provide evidence of a positively significant correlation between $\mathrm{CO}_{2}$ emission and urbanization in Nigeria. The ARDL bounds test confirmed a cointegration nexus among the variables in the long-term. From the ARDL estimation result; urbanization, GDP, and trade negatively affect carbon emissions in the short-term and long-term in Nigeria. Energy consumption shows a positively significant nexus with carbon emissions in the short-term and long-term, taking into account breaks. This, by implication, means that, as urbanization, GDP, and trade incline towards reducing the amount of carbon emission into the atmosphere in the long run, energy use causes the environmental quality to diminish. This could be as a result of the migrants' exposure to more efficient energy products, such as the renewable energy products, which aid against the use of inefficient energy products, such as oil equivalent energy use, which contributes more to carbon emission. From the causality test result, findings suggest carbon emissions drive urbanization in Nigeria. The study concludes from the findings that urbanization is not a significant factor in contributing to an increase in carbon emissions, but rather energy use. However, we recommend policies to reduce the amount of carbon emission through energy conservation, and that efficiencies should be adopted. This is achievable through the adoption of efficient renewable energy technologies.

\section{REFERENCES}

Abdallh, A. A., \& Abugamos, H. (2017). A semi-parametric panel data analysis on the urbanization-carbon emissions nexus for the MENA countries. Renewable and Sustainable Energy Reviews, 78, 1350-1356.

Adusah-Poku, F. (2016). Carbon Dioxide Emissions, Urbanization and Population: Empirical Evidence in Sub Saharan Africa. Energy Economics Letters, 3(1), 1-16.

Ali, H. S., Abdul-Rahim, A., \& Ribadu, M. B. (2016). Urbanization and carbon dioxide emissions in Singapore: evidence from the ARDL approach. Environmental Science and Pollution Research, 24(2):1967-1974.

Ali, H., Law, S., \& Zannah, T. (2016). Dynamic impact of urbanization, economic growth, energy consumption, and trade openness on CO2 emissions in Nigeria. Environmental Science Pollution Resources, 23(12), 12435-12443. doi:DOI 10.1007/s11356-016-6437-3

Bilgili, F., Koçak, E., Bulut, Ü., \& Kuloğlu, A. (2017). The impact of urbanization on energy intensity: panel data evidence considering cross-sectional dependence and heterogeneity. Energy. 133, 242-256. DOI: 10.1016/j.energy.2017.05.121, 1-41.

Bloom, D., Canning, D., \& Fink, G. (2008). Urbanization and the wealth of nations. Science, 319(5864), $772-775$.

De Leon Barido, D. P., \& Marshall, J. D. (2014). Relationship between Urbanization and CO2 Emissions Depends on Income Level and Policy. Environmental Science Technology. 48(7), 3632-3639.

Enete, I. C., \& Ayadiulo, R. U. (2012). Urbarinzation and the Challenge of Climate Change in Nigeria. Cities: A Review. IOSR Journal Of Environmental Science, Toxicology And Food Technology, 1(6), 13-18.

Glaeser, E. (2011). Cities, productivity, and quality of life. Science, 333(6042), 592-594.

He, Z., Xu, S., Shen, W., Long, R., \& Chen, H. (2016). Impact of urbanization on energy related $\mathrm{CO}_{2}$ emission at different development levels: Regional difference in China based on panel estimation. Journal of Cleaner Production, 140(3), 1719-1730.

Liu, F., Yu, M., \& Gong, P. (2017). Aging, Urbanization, and Energy Intensity based on Cross-national Panel Data. Procedia Computer Science, 122, 214-220. 
Liu, Y., \& Xie, Y. (2013). Asymmetric adjustment of the dynamic relationship between energy intensity and Urbanization in China. Energy Economics, 36, 43-54.

Martínez-Zarzoso, I. (2008). The Impact of Urbanization on $\mathrm{CO}_{2}$ Emissions: Evidence From Developing Countries. Ecological Economics. 70(7), 1344-1353. https://doi.org/10.1016/j.ecolecon.2011.02.009.

Ouyang, X., \& Lin, B. (2016). Carbon dioxide $\left(\mathrm{CO}_{2}\right)$ emissions during urbanization: A comparative study between China and Japan. Journal of Cleaner Production, 143, 356-368.

Pata, U. K. (2017). The effect of urbanization and industrialization on carbon emissions in Turkey: evidence from ARDL bounds testing procedure. Environmental Science and Pollution Research. 25(8):7740-7747. doi.org/10.1007/s11356-017-1088-6.

Pesaran, H. M., Shin, Y., \& Richard, S. J. (2001). Bounds testing approaches to the analysis of level relationships. Journal of Applied Econometrics, 16(3), 289-326.

Poumanyvong, P., \& Kaneko, S. (2010). Does urbanization lead to less energy use and lower $\mathrm{CO}_{2}$ emissions? A cross-country analysis. Ecological Economics, 70(2), 434-444.

Rafiq, S., Salim, R., \& Nielsen, I. (2016). Urbanization, openness, emissions and energy intensity: A study of increasingly urbanized emerging economies. Energy Economics. 56, 20-28. DOI: doi: 10.1016/j.eneco.2016.02.007, 1-30.

Sadorsky, P. (2014). The effect of urbanization on $\mathrm{CO}_{2}$ emissions in emerging economies. Energy Economics, 41, $147-153$.

Sadorsky, P. (2013). Do urbanization and industrialization affect energy intensity in developing countries? Energy Economics, 37, 52-59.

Sheng, P., \& Guo, X. (2016). The Long-term and Short-term Impacts of Urbanization on Carbon Dioxide Emissions. Economic Modelling, 53, 208-215.

Stewart, C. T., \& Lee, J-H. (1986). Urban concentration and sectoral income distribution. The Journal of Developing Areas, 20(3), 357-368.

Wang, Y., Zhang, X., Kubota, J., Zhu, X., \& Lu, G. (2015). A semi-parametric panel data analysis on the urbanizationcarbon emissions nexus for OECD countries. Renewable and Sustainable Energy Reviews. 48, 704-709.

Wang, Yuan; Chen, Lili; Kubota, Jumpei. (2016). The relationship between urbanization, energy use and carbon emissions: evidence from a panel of Association of Southeast Asian Nations (ASEAN) countries. Journal of Cleaner Production., 112, 1368-1374.

Yang, Y., Liu, J., \& Zhang, Y. (2017). An Analysis of the Implications of China's Urbanization Policy for Economic Growth and Energy Consumption. Journal of Cleaner Production. 161, 1251-1262.

Zhang, N., Yu, K., \& Chen, Z. (2017). How does urbanization affect carbon dioxide emissions? A cross-country panel data analysis. Energy Policy. 107, 678-687. http://dx.doi.org/10.1016/j.enpol.2017.03.072, 1-10.

Zhu, H.-M., You, W.-H., \& Zeng, Z.-f. (2012). Urbanization and $\mathrm{CO}_{2}$ emissions: A semi-parametric panel data analysis. Economics Letters, 117, 848-850.

Zi, C., Jie, W., \& Hong-Bo, C. (2015). $\mathrm{CO}_{2}$ emissions and urbanization correlation in China based onthreshold analysis. Ecological Indicators. 61, 193-201. 
EJAE $2020 \diamond 17(2) \diamond 161-177$

SHEHU. M. ๖ DOES URBANIZATION INTENSIFY CARBON EMISSIONS IN NIGERIA?

\begin{tabular}{|c|c|c|c|c|c|}
\hline year & $\begin{array}{c}\text { Carbon } \\
\text { Emission (kt) }\end{array}$ & $\begin{array}{l}\text { GDP per Capita } \\
\text { (current LCU) }\end{array}$ & $\begin{array}{c}\text { Energy Use } \\
\text { per capita } \\
\text { (oil equivalent) }\end{array}$ & $\begin{array}{c}\text { Urban } \\
\text { Population } \\
\text { (ratio of total) }\end{array}$ & $\begin{array}{c}\text { Trade } \\
\text { (\% of GDP) }\end{array}$ \\
\hline 1971 & 32280.6 & 181.0867 & 579.0964 & 18.151 & 0.244636 \\
\hline 1972 & 41426.1 & 188.1045 & 585.4539 & 18.549 & 0.227636 \\
\hline 1973 & 49577.84 & 203.8182 & 597.1382 & 18.952 & 0.312678 \\
\hline 1974 & 62291.33 & 317.8672 & 600.4265 & 19.363 & 0.39747 \\
\hline 1975 & 47395.98 & 362.0658 & 608.4557 & 19.78 & 0.411703 \\
\hline 1976 & 55247.02 & 438.6487 & 622.2918 & 20.205 & 0.421381 \\
\hline 1977 & 50567.93 & 499.6593 & 636.2368 & 20.636 & 0.473953 \\
\hline 1978 & 48294.39 & 520.2937 & 645.8924 & 21.074 & 0.433148 \\
\hline 1979 & 70289.06 & 601.0817 & 653.1639 & 21.518 & 0.438784 \\
\hline 1980 & 68154.86 & 684.3113 & 665.1001 & 21.97 & 0.485713 \\
\hline 1981 & 65958.33 & 685.3477 & 676.3869 & 22.671 & 0.482933 \\
\hline 1982 & 65602.63 & 692.6157 & 691.7809 & 23.389 & 0.377485 \\
\hline 1983 & 59929.78 & 729.4444 & 693.5561 & 24.122 & 0.270372 \\
\hline 1984 & 69625.33 & 789.3021 & 677.7652 & 24.872 & 0.236089 \\
\hline 1985 & 69893.02 & 879.5493 & 682.8194 & 25.635 & 0.259001 \\
\hline 1986 & 73505.02 & 872.868 & 671.499 & 26.414 & 0.237168 \\
\hline 1987 & 59343.06 & 1270.271 & 676.8561 & 27.209 & 0.416467 \\
\hline 1988 & 70747.43 & 1635.607 & 678.8559 & 28.019 & 0.35312 \\
\hline 1989 & 42441.86 & 2460.585 & 684.4483 & 28.842 & 0.603918 \\
\hline 1990 & 38162.47 & 2955.288 & 697.1921 & 29.68 & 0.530302 \\
\hline 1991 & 40014.3 & 3367.268 & 712.2482 & 30.176 & 0.648766 \\
\hline 1992 & 64289.84 & 5542.176 & 721.9704 & 30.677 & 0.61031 \\
\hline 1993 & 58268.63 & 6960.196 & 715.4378 & 31.182 & 0.581098 \\
\hline 1994 & 44865.75 & 8974.894 & 680.7101 & 31.691 & 0.423089 \\
\hline 1995 & 33267.02 & 18595.84 & 682.2696 & 32.205 & 0.597678 \\
\hline 1996 & 38936.21 & 25277.37 & 693.7783 & 32.725 & 0.57691 \\
\hline 1997 & 40175.65 & 25603.91 & 699.6507 & 33.247 & 0.7686 \\
\hline 1998 & 40164.65 & 24198.89 & 687.1179 & 33.773 & 0.661732 \\
\hline 1999 & 44774.07 & 27757.66 & 694.1713 & 34.304 & 0.558464 \\
\hline 2000 & 79170.53 & 38555.41 & 703.2447 & 34.84 & 0.713805 \\
\hline 2001 & 83339.91 & 39131.13 & 720.0472 & 35.669 & 0.818128 \\
\hline 2002 & 98114.25 & 55400.52 & 724.6113 & 36.508 & 0.633836 \\
\hline 2003 & 93130.8 & 66245.96 & 746.6122 & 37.356 & 0.752189 \\
\hline 2004 & 97039.82 & 86219.74 & 748.3413 & 38.212 & 0.484481 \\
\hline 2005 & 104689.2 & 106055.7 & 757.9587 & 39.074 & 0.507484 \\
\hline 2006 & 98891.66 & 131191.7 & 744.5452 & 39.943 & 0.646093 \\
\hline 2007 & 95055.97 & 143022.4 & 750.7831 & 40.819 & 0.644629 \\
\hline 2008 & 96148.74 & 164055 & 752.8598 & 41.702 & 0.64973 \\
\hline 2009 & 76735.64 & 163443.7 & 721.4534 & 42.588 & 0.618029 \\
\hline 2010 & 92016.03 & 349791.6 & 755.9892 & 43.48 & 0.426514 \\
\hline 2011 & 96093.74 & 391174.5 & 778.4994 & 44.362 & 0.527941 \\
\hline 2012 & 99636.06 & 433955.8 & 798.3031 & 45.234 & 0.443801 \\
\hline 2013 & 95650.03 & 471456.1 & 779.8515 & 46.094 & 0.310489 \\
\hline 2014 & 99741.91 & 510805.4 & 763.3914 & 46.942 & 0.308852 \\
\hline 2015 & 101750.1 & 525316.4 & 746.9312 & 47.776 & 0.211244 \\
\hline
\end{tabular}

Source: World Development Indicators (2016) 


\section{DA LI URBANIZACIJA POJAČAVA EMISIJU UGLJENIKA U NIGERIJI?}

\section{Rezime:}

Ova studija ispituje odnos urbanizacije i emisije $\mathrm{CO}_{2} \mathrm{u}$ Nigeriji primenom metode autoregresivne distribucije kašnjenja (ARDL) za analizu podataka o godišnjim vremenskim serijama u rasponu od 1974. do 2015. Rezultati studije sugerišu da urbanizacija, BDP, upotreba energije i emisija ugljen dioksida snažno i pozitivno. koreliraju, dok trgovina i emisije ugljen dioksida pokazuju slabu i negativnu korelaciju. Rezultat ARDL pokazuje negativno značajnu kratkoročnu i dugoročnu vezu između urbanizacije i emisije ugljen dioksida u ekonomiji Nigerije. Kratkoročno, BDP, trgovina i upotreba energije pozitivno utiču na emisiju ugljen dioksida, dok dugoročno trgovina i BDP negativno utiču na emisiju ugljen dioksida upotrebom energije koja ima pozitivan uticaj na emisiju ugljen dioksida. Stoga, studija zaključuje da urbanizacija ne uzrokuje porast emisije ugljen dioksida u Nigeriji, ali upotreba energije uzrokuje. Na osnovu rezultata preporučena je neophodnost upotrebe štedljive energije i ekološki prihvatljive tehnologije za smanjenje količine emisije ugljenika u ekonomiji.
Ključne reči:

ARDL, emisije $\mathrm{CO}_{2}$, STIRPAT model, urbanizacija. 